酒亡漠詩 (3)

\title{
杜 甫
}

縄 田 正 造

1. 何レノ時カー樽ノ酒, 重ネテ贞ニ細カニ文論ゼン

いつの日になったら, 同じ掼から酒を酷み交わし、またすいっしょに事こまかに, 文学を語り合えるだろうか。

天下で共に詩文を論じ合える者, 君以外にはないと畏 敬親愛の意を寄す。詩題「春日李白憶ウ」。杜甫は李
白より 11 歳年下であるが, 二人には親交があり, 何首 かの贈答の詩が残っている。

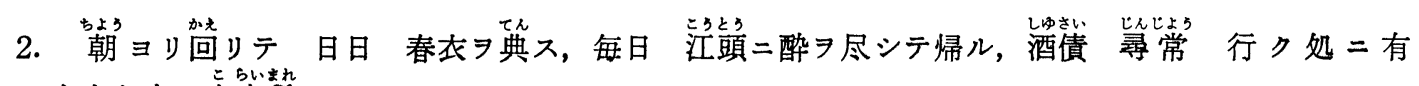
リ, 人生七十 古来稀ナり

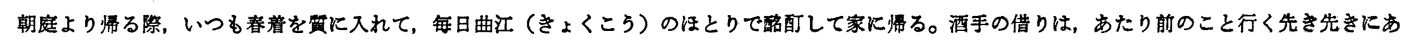
る。ままよ, 人生 70 まで生きるといらことは, 昔から稀なことだ。

この詩は, 杜甫が長安に在って, 朝廷に仕官した得意＼cjkstart語句より出たものである。詩題「曲江」 の時代の作である。世に 70 歳を古稀といらのは, この

3. 思ウナカレ 身外無窮ノ事 7 , 且ツ尽クセ 生前有限ノ杯

我が身に関係のない無数無限の事柄に，いたずらに気をるむなよ。まあまあ，生きているらちに，限りある杯で楛を引くことにしよらではないか。

前句に，漸く老いてまた春にめぐり逢った。あと幾 たび春に逢えるやら，とある。生前有限とは，人生は有

限であり, 従って飲む酒の量も有限との意。詩題「絶句 漫興」。漫興とは偶作のこと。

4. 沈飲モテ 聊カ遣リ, 放歌モテ 愁絶鸟破ル

大酒にひたって，少しでも自分から父分を暗らし，次いで歌いまくって，烈しい覌然をぶっ飛ばそら。

前句に，自分の素心をかえて，世搭て人となることは できぬとある。

杜甫は李白と併称される 盛唐の大詩人であるが, 性 格，作風は全く異る。杜甫は努力家で悲憤㤹慨型であ り，世の中の暗黒面を眺め探り取上げる。社会詩人と称 される所以である。進士の試験を受けたが及第せず，官
途についたのは僅かの間で, 各地漂泊に身をまかす。杜 甫は, 一生憂ら, といわれ, 一生を通じて, 人間の悲哀 や世間の苦患を詠じ続けた。死期前 2 年は舟でさまよい 続け, 湘江に浮かぶ舟の中で病没した。時に 59 歳。詩 題「詠懁五百字」。

5. 此ノ身 醒メ復タ酔ウ, 興ニ乗ジテハ即チ家トナサン

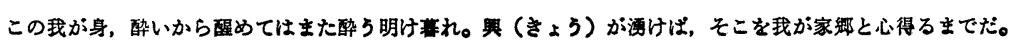

前句に，世路には障害が多いが，どうせ限りある我が詩句。詩題「春帰」

人生だ, とある。随処漂泊する不遇落魄の身を詠した

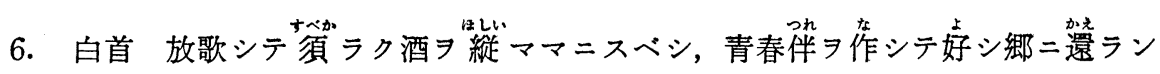

この白頭をふりたて歌を歌いまくり、弐張って存分に酒を飲まねばならぬ。この春には一家連れ立って、いざ故郷，洛陽に㷌るとしょう。 
前句に，洛陽に侵入（史思明の叛乱）した賊軍が，討 伐されたと聞いて涙を流し，妻子を顧み書物を読み芷し て狂喜したとある。

杜甫が社会の不条理, 庶民の救いのない苦難に鋭く言 及した多くの詩作の根底にあるものは, 経世済民の伝統
的な儒道であったといわれる。詞鋒によってその信条を 吐露し, 後世多くの人々に尊敬されまた感化を与えた。 杜甫が「詩聖」とたたえられる所以である。詩題 (意) 「官軍ノ平定习聞ク」。

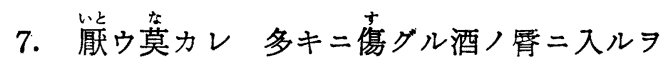

また遗ぎるといって，とがめ立てされる酒を，今日は心置きなく吃とそぎこする。

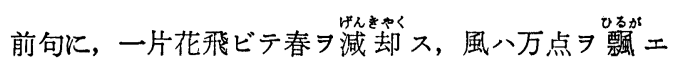
シテ正ニ人ヨ愁エシム, とある。

花びらが一片散ってさ光，春はそれだけ減ずる。まし
て夕嵐に花吹雲, 万花网しく枝を辞す。まさに愁嘆。逝 く春, 散る花。禁酒もものかわ。春に惜別, 花に懐古の 酒を酸まん。君，停むる勿れ。詩題「曲江」

8. 觜テ隣翁ト相対シテ飲マンヤ, 籬

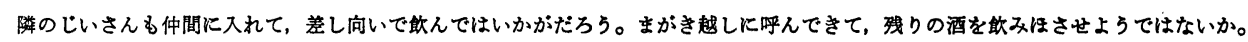

前句に, 久しく来客がないのに, 今日珍らしく客があ くことにしよう。詩題「客至ル」 ったとある。座持ちがうまい剽軽者の隣家の老人を招

9. 書ヨ読ム二難字過シ, 酒ニ対シテ満壸頻リナリ

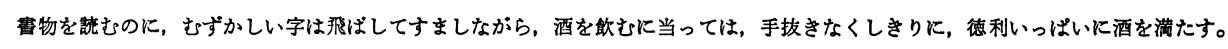

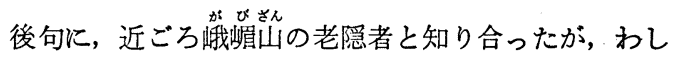
のものぐさを理解してくれたとある。ただに日暮らし，

読む書くさては飲むだけの世過ぎである。詩題「漫成」 (そぞろ言の作)

10. 第蜀醪 誰カ汝

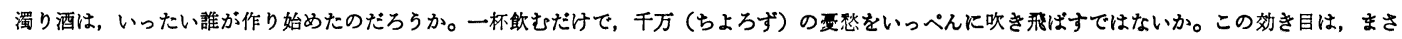
に摩訶（まか）不思議の㫛術（まじない）か。

中国古代に杜康という人が，はじめて酒を作ったとい たのであろう。酒は憂いの玉ぼうきという。らべなるか ら伝説がある。それを杜甫が知らぬ筈はなく，空とぼけ な。詩題「落日」

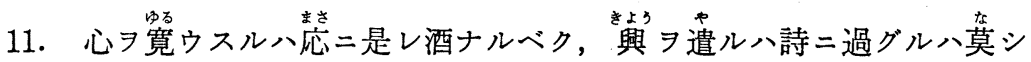

心をくつろがせるには，まさしく酒かふさわしい。感興をふるいおこすには，詩より良いるのはない。生涯の伴侣は酒と詩である。

後句飞, 此ノ意萄潜ノミ解ス, 吾が生 汝ノ期二後 レタリ,とある。即ち, この詩の意味は陶淵明だけには 理解されるであろう。私の生れるのが，あなた（陶淵 明）より技そかったのが残念でならぬ。同時代に生れた ならば，師弟となり或は親友となり，栗里の隠所に於
て，酒を酌み交わし世を論じ詩を語り合ったであろう К。

靖節先生とおくりなされた陶淵明は, 後世多くの詩人 たちより仰望, 敬慕の讃辞を奉られた。詩題「惜シム可 シ」

12. 敏捷 詩千首, 栾虏零 酒一杯

彼はすばしこい才能を持ち、たちどころに千首の詩を作るはどであるが，今は流浪し等落し，一杯の酒に甭さを明らしているだろら。

前句に，李白の消息なく見ないこと久しいとある。李 白が安禄山の乱にまきこまれ，投獄されまた流罪となっ
た頃 (後に赦免)，李白の身を案じての作である。詩題 「見ズ」(久しく李白を見ない) 


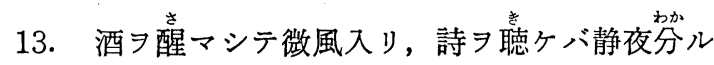

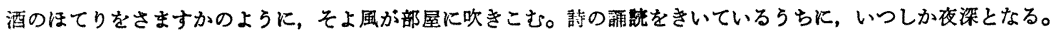

宿した山荘の寝室にまで，天井にとどく書棚がある。

階しの前の高い樹は雲を払い, 月光はゆれる゙梢で乱れ散

る。杜甫は自分の貧困な暮らしにくらべ, こんな別天地で
の幽雅な世過ぎもあるのかと，感嘆しきりである。詩 題「荷将軍ノ山林二遊ブ」

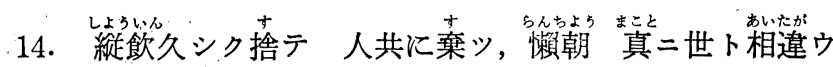

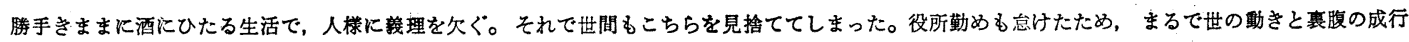
きとなった。

安禄山の乱も怙さまったとき,杜甫ば网江の岸の春景 色の中に立つ。桃の花に楊の花，らぐいすに白鳥を眺め，
ひとり酒をくみながら，この詩を作った。，その詩䫓に哀 愁と絶望のひびきが濃い。詩題「曲江ニテ酒ニ対ス」

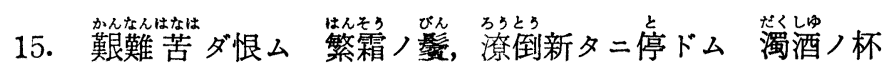

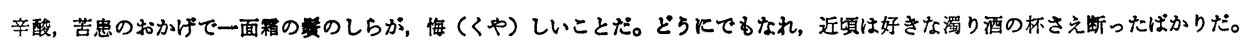

前句に, 悲しい秋, 放浪の身, 生涯の多病をしみじみ と嘆いている。

杜甫は出倫の才を駆使して, 律詩の句法を磨き律詩形
式を完成させた。かくて杜甫の律詩は, 後世の詩人たち の最高の手本となる。詩題「登高」(七言律詩)。上の （熯難……杯）句は，そ終のりの聯である。

16. 夜二八長沙ノ酒二酔イ, 暁ニ八湘水ノ春二行ク

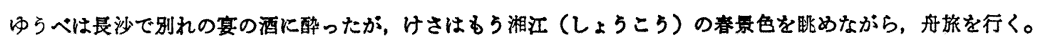

岸に咲く花は，旅人の私に別れを惜しむかのように， 花びらを散らす。帆柱にとまるつばめは，私を引き止め るかのように語りかける。この地に流菲となった先賢 2
人をしのべば,ひとしお心が痛むと，後句にある。岸の 花，つばめ，先賢に託して，この地を去る心残りを詠ん た。杜甫死去の前年の作。詩題「潭州 7 発ツ」

（次回は白居易）

\section{蒸しと䴸のコンサルタント}

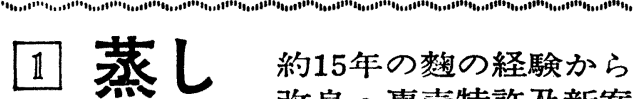
改良・尃売特許及新案 約 8 件・コシキ理論を忠実に改良 二五こしき（断熱材使用） 横式連続蒸煮装置
2 䊍各地名醽家でご採用

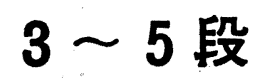

薄盛式自動製䴹機

株式会社

ハク

干171 東京都豊島区長崎 2-17-15

TEL (03) $959-3366$ 